\title{
Mind mapping: Its usefulness and effectiveness in CTU101 \& CTU151 courses
}

\author{
Norazmi Anas ${ }^{1, *}$, Shahril Nizam Zulkipli ${ }^{1}$, Mohd Syukri Mohd Noor ${ }^{1}$, Abd Munir Mohamed Noh ${ }^{1}$, Mohamed \\ Imran Mohamed Ariff ${ }^{2}$, Zulkifli Mohd. Ghazali ${ }^{2}$, Zuriani Yaacob ${ }^{3}$, Intan Noorazlina Abdul Rahim ${ }^{4}$, Hartini Mohd \\ Rosli $^{4}$
}

${ }^{1}$ Academy of Contemporary Islamic Studies, Universiti Teknologi MARA, Tapah Campus, Perak, Malaysia ${ }^{2}$ Faculty of Computer \& Mathematical Sciences, Universiti Teknologi MARA, Tapah Campus, Perak, Malaysia ${ }^{3}$ Academy of Language Studies, Universiti Teknologi MARA, Raub Campus, Pahang, Malaysia ${ }^{4}$ Department of General Studies, Kolej Poly Tech MARA Kuantan, Pahang, Malaysia

\section{A R T I C LE IN F O}

Article history:

Received 23 November 2016

Received in revised form

9 March 2017

Accepted 10 April 2017

Keywords:

I-MAPS

CTU101

CTU151

UiTM

\begin{abstract}
A B S T R A C T
This paper is intended to expose the public to Interactive Mind Mapping for CTU101 (Basic Principles of Islam) and CTU151 (Islamic Thought and Civilization) courses that have been developed based on structured questionnaires distributed to universities using IBM SPSS Software, version 21. Obviously, the findings of the study have become the foundation in establishing I-MAPS application that can be possibly accessed through available modern gadgets. In a constantly changing world, this effort is significant in order to increase one's knowledge and understanding.

(C) 2017 The Authors. Published by IASE. This is an open access article under the CC BY-NC-ND license (http://creativecommons.org/licenses/by-nc-nd/4.0/).
\end{abstract}

\section{Introduction}

The use of a diagram or a mind map has been practiced by the Prophet Muhammad (PBUH) when he was explaining to his friends through the hadith narrated by 'Abd Allah bin Mas'ud, the Prophet Muhammad (PBUH) drew a square, then he drew a line in the middle of it and let it extend outside the square and he drew several small lines attached to that central line. It serves as a clarification that (each line) is the human being (square) is the inevitable death and (the line which is outside the square) is the never-ending of human being hope (Sahih Bukhari). Therefore, it is applicable that the methods of sketching diagrams or mind maps to be used as learning approach to the subject of religion. The aim of this study is to develop Interactive Mind Map model for Diploma students of Universiti Teknologi MARA (UiTM) through CTU101 course (Basic Principles of Islam) and CTU151 (Islamic Thought and Civilization).

\section{Literature review}

Mind map is a graphic picture of topic, idea and relationship between both hierarchy and stage

\footnotetext{
* Corresponding Author.

Email Address: norazmianas@perak.uitm.edu.my (N. Anas) https://doi.org/10.21833/ijaas.2017.05.012

2313-626X/C 2017 The Authors. Published by IASE.

This is an open access article under the CC BY-NC-ND license

(http://creativecommons.org/licenses/by-nc-nd/4.0/)
}

(Novak, 2015) which increases the process of teaching and learning in the class through four strategies/categories (Katagall et al., 2015) for example (I) Planned Learning Strategy (ii) Teaching strategy (iii) Planned Curriculum Strategy and (iv) Students Understanding Evaluation Method. If the students are able to capture and manipulate complex set through diagrams, they will memorize, understand and analyze easier (Davies, 2011; Chiou, 2008) thus they can improve capability, increase students motivation (Rofi'i et al., 2014) and they can participate actively (Twardy, 2004) in order to achieve effective teaching and learning (T\&L). Sherbone (2014) described mind map concept as a way that can help the process of curriculum development from various levels as premier idea to be implemented in the class for focus development and collaboration between educators and students. Nowadays, the biggest obstacle in teaching and learning (T\&L) is the use of modern gadgets for example smart phone, tablet and others especially to Y generation, we need to manipulate all; that it can give a great impact to cyber generation. In addition, Interactive Mind Map is seen as one of the tools for new teaching and learning application of modern technology compared to the conventional mind map which is easy to access, clearer and effective as well as engaging (Liu et al., 2015). It is in line with research by Jablokow et al. (2015) and Londers et al. (2015) in the field of engineering, Vitulli et al. (2014) in the field of visual arts and MacKinnon et al. (2014) in four different higher educations for example 
medicine, English literature, Greek methodology and architecture. Therefore the concept of interactive mind map will be more interactive and flexible to the students not only at school level but also to the students in higher education.

CTU101 course (Basic Principles of Islam) and CTU151 (Islamic Thought and Civilization) are two Islamic Education courses that are compulsory for diploma semester 1 and 2 students in Universiti Teknologi MARA (UiTM). Both courses offer the knowledge and understanding of the basic Islamic concept and Islamic civilization and they are taught for 14 weeks. Students are exposed to the basic principles in Islam that is focused on the aspect of faith, sharia', worship or ibada and morals in CTU101 course. More emphasis is given about the importance of understanding and appreciating faith as well as the application of sharia', worship or ibada and morals in daily life. This course is stated as a university course and has two credit hours and also two contact hours. The course outcomes are (i) Explaining Islam as Ad-Din, (ii) Connecting the concept of faith as life's basic, and (iii) Applying the needs of sharia', worship or ibada \& morals in selfdevelopment, society and country. The content of the syllabus includes five (5) subtopics which are; Islam as Ad-Din, Faith is the core of Muslim Development, Sharia' in Muslim's Life, Worship Creates Quality in Human and Morals in Developing Oneself. CTU151 explains the Islamic Civilization concept and its contribution to the world's civilization. The discussion of the course includes Islam in Malay world, family institution, socialization and Islamic kinship and its challenge faced by the current Islamic World.

These courses are stated as a university course and have two credit hours and also two contact hours. The course outcomes are (i) Explaining the concept of Islamic Civilization and its contribution to the world's civilization. (ii) Explaining the growth and the influence of Islam in the Malay world and (iii) describing the social system and Islamic statehood as well as the challenge that is faced by today's Muslim. There are five (5) main syllabus content that includes the Concept of Islamic Civilization, Universal Values in Islamic Civilization, The Development of Islamic Civilization, Islamic Civilization Thought and Islam in Malay World.

\subsection{I-MAPS}

I-MAPS Development Project was approved through UiTM 2015 internal research grants i.e. Academic \& Research Assimilation (ARAS) entitled Interactive Mind Map Model: CTU101 \& CTU151 initiating December 1, 2015 - 30 May 2017 (18 months) of RM 5,000.00. The research team comprises Norazmi Anas (Principal Investigator), Shahril Nizam Zulkipli, Mohd. Syukri Mohd. Noor, Abd. Munir Mohamed Noh \& Nurul Hidayah Aziz from Academy of Contemporary Islamic Studies (ACIS, UiTM Tapah, Perak Campus) and Dr. Mohamed Imran Mohamed Ariff \& Zulkifli Mohd.
Ghazali from the Faculty of Computer Science and Mathematics (FSKM, UiTM Tapah, Perak Campus).

In addition, collaboration has been carried out by the researchers with the Department of General Studies, Kolej Poly-Tech MARA, Kuantan, Pahang Campus with hope that it may strengthen the research network via paper presentations and article publications in international journals. The initial target set by the research team is presenting two research papers in national and international conferences, two entries in international innovation competition and a publication of journal article indexed in SCOPUS / ISI.

The investigation was initiated with the questionnaire distributed to Semester 1 and 2 diploma students of UiTM Tapah, Perak Campus taking CTU101 dan CTU151 courses of 2016/2017 session. This is to identify the students' perceptions regarding the use and effectiveness of the concept of mind mapping to be practiced in the process of teaching and learning in both courses.

Besides that, a conceptual paper entitled Development of Interactive Mind Map Model: CTU101 \& CTU151 was presented at the International Conference on Social Sciences and Humanities (PASAK2016), organized by the Centre for Core Studies, International Islamic University College Selangor (KUIS) on 20-21 April 2016, followed by the development of the prototype IMAPS $101 \& 151$ version 1.0 which was contested at the International Innovation in Teaching and Learning (i-InTeL2016) organized by UiTM Kedah, Merbok Campus on 27-28 July 2016.

The prototype has been upgraded to version 2.0 and later competed in the 5th Innovation, Invention and Design (INDES2016) organized by UiTM Perak, Seri Iskandar Campus from 9 to 10 November 2016. The product has been recognised and eventually won the silver medal in the category of Education \& ICT.

The second paper entitled Usefulness and Effectiveness of Mind Mapping: An Analysis of CTU101 \& CTU151 Courses will be presented at the Regional Conference on Sciences, Technology and Social Sciences (RCSTSS2016) organized by UiTM Pahang Campus at Copthorne Hotel, Cameron Highlands on 4 - 6 December 2016. This will be followed by the publication of a journal article indexed in SCOPUS / ISI in order to meet the requirements and the Key Performance Index (KPI) of UiTM ARAS grant.

\section{Methodology}

The design of the research involved qualitative method using questionnaires to identify the usage and the effectiveness of mind mapping concept that is used in teaching and learning (T\&L) in classroom situation. The questionnaire data is taken by cluster sampling of the diploma students of Universiti Teknologi MARA (UiTM) Perak, Tapah campus, that have already taken CTU101 and CTU151 courses (2nd and 3rd semester). The number of current 
diploma students of UiTM Perak, Tapah campus is more than 5000. Therefore, according to Krejcie and Morgan (1970), the sampling size that is suitable are 357 respondents including three faculties, (i) Faculty of Applied Sciences - 120 respondents, (ii) Faculty of Accountancy - 120 respondents and (iii) Faculty of Computer and Mathematical Sciences - 120 respondents.

The questionnaire is divided into three sections namely section A, B \& C. Section A is on the respondents' demographic data (6 items) whereas section $B$ and $C$ focus on the usage and the effectiveness of mind mapping in T\&L, 10 and 8 items each. The questionnaires data is analyzed using IBM SPSS 21.0 in order to gain the descriptive data, correlation and model as planned.

\section{Results and discussion}

\subsection{Reliability test}

Table 1 shows the Cronbach Alpha value for the pilot study performed in this research. The Cronbach Alpha value in Table 1 indicates that all the items in the questionnaire is reliable as supported by Sekaran (2006) - Cronbach's Alpha value that are greater than 0.80 are considered good.

Table 1: Cronbach's alpha value of latent variables

\begin{tabular}{cccc}
\hline Construct & Subscales & No of Items & Cronbach's Alpha \\
\hline \multirow{2}{*}{ Usefulness } & $\begin{array}{c}\text { Teaching \& Learning } \\
\text { Revision }\end{array}$ & 6 & 0.789 \\
& & 4 & 0.816 \\
Effectiveness & & 8 & 0.908 \\
\hline
\end{tabular}

\subsection{Descriptive analysis}

Table 2 summarizes the participants' background in this study. A total of 360 questionnaires were distributed. However, only 350 questionnaires were returned. Upon, performing data cleaning only 346 questionnaires were useable. The participants whom had responded in this research consist of $28.3 \%$ male and $71.7 \%$ female from three faculties. There are $34.1 \%, 44.2 \%$ and $21.7 \%$ from Faculty of Computer and Mathematical Sciences (FSKM), Faculty of Accountancy (FP) and Faculty of Applied Sciences (FSG) respectively. The respondents from FSKM are divided into four courses such as Diploma in Statistics, Mathematics, Actuary and Computer Sciences with the percentage is $2.9 \%, 5.5 \%, 15.9 \%$ and $9.8 \%$ respectively.

Table 2: Respondent's background

\begin{tabular}{|c|c|c|c|}
\hline & Items & Frequency & Percentage (\%) \\
\hline \multirow{2}{*}{ Gender } & Male & 98 & 28.3 \\
\hline & Female & 248 & 71.7 \\
\hline \multirow{3}{*}{ Faculty } & Faculty of Computer and Mathematical Sciences (FSKM) & 118 & 34.1 \\
\hline & Faculty of Accountancy (FP) & 153 & 44.2 \\
\hline & Faculty of Applied Sciences (FSG) & 75 & 21.7 \\
\hline \multirow{6}{*}{ Course } & Diploma in Statistics & 10 & 2.9 \\
\hline & Diploma in Mathematics & 19 & 5.5 \\
\hline & Diploma in Actuary & 55 & 15.9 \\
\hline & Diploma in Computer Sciences & 34 & 9.8 \\
\hline & Diploma in Accounting & 75 & 21.7 \\
\hline & Diploma in Sciences & 153 & 44.2 \\
\hline
\end{tabular}

Table 3 provides a summary of descriptive statistics for three latent variables. Based on these results, the mean value for effectiveness of mind mapping is 3.92. This indicates that the respondents agreed that mind mapping has a good effect on CTU101 and CTU151 courses. However, the mean value of usefulness of mind mapping in teaching and learning and revision are smaller than effectiveness which are 3.56 and 3.64 respectively. The both values of mean are between "not sure" and "agree". This could be speculated that mind mapping concept is not fully used by lecturers in UiTM Perak.

Table 3: Descriptive statistics of latent variables

\begin{tabular}{cccccc}
\hline Items & Sample Size & Min & Max & Mean & Mode \\
\hline Usefulness (Teaching \& Learning) & 346 & 1 & 5 & 3.56 & 3.67 \\
Usefulness (Revision) & 346 & 1 & 5 & 3.64 & 4 \\
Effectiveness & 346 & 1 & 5 & 3.92 & 4 \\
\hline
\end{tabular}

\subsection{Correlation analysis}

Table 4 shows the correlation value of latent variables obtained using the Pearson's Correlation method. Based on the results, there is a positive correlation between each variable as the correlation values are between $0.788,0.727$ and 0.731 respectively. This research employs a correlation value significant at 0.01 . The correlation values indicate that the usefulness of mind mapping in Teaching and Learning and Revision are positively correlated to the effectiveness in CTU101 and CTU151 courses. 


\section{Conclusion}

The main objective of this research is to investigate the usefulness and effectiveness of mind mapping concept in CTU101 and CTU151 courses respectively. Based on the results above, the mean value of effectiveness of mind mapping in teaching and learning is 3.92. This suggests, majority of the students agree that mind mapping support their learning in the respective courses. Further, the mean values of usefulness of mind mapping in teaching and learning and revision are less than the effectiveness of mind mapping which are 3.56 and 3.64 respectively. The values of this mean are between "not sure" and "agree". This could be speculated that mind mapping concept is not fully used by lecturers in UiTM Perak. In contrast, students agree that mind mapping concept is useful during their revision thus is effective in the teaching and learning (mode $=4$ ). Based on the correlation analysis, there is a moderate positive correlation between usefulness (teaching and learning), usefulness (revision) and effectiveness of the mind mapping concept. This suggests that the effectiveness of the mind mapping concept are good related to the usefulness of mind mapping in teaching and learning and students revision. Finally, as conclusion, this research implies that students are interested to use the mind mapping concept for teaching and learning and revision in the CTU101 and CTU151. This result also implies that the development of the Interactive Mind Mapping (IMAPS) application for CTU101 and CTU151 would be worthwhile.

Table 4 Correlation between latent variables

\begin{tabular}{cccc}
\hline Variables & Usefulness (Teaching \& Learning) & Usefulness (Revision) & Effectiveness \\
\hline Usefulness (Teaching and Learning) & 1 & & \\
Usefulness (Revision) & $0.778^{* *}$ & 1 & \\
Effectiveness & $0.727^{* *}$ & $0.731^{* *}$ & 1 \\
\hline
\end{tabular}

\section{Acknowledgement}

This work was supported by Universiti Teknologi MARA (106215160006) under the ARAS (Academic \& Research Assimilation) Research Grant 2015 and collaboration with Kolej Poly-Tech MARA Kuantan.

\section{References}

Chiou CC (2008). The effect of concept mapping on students' learning achievements and interests. Innovations in Education and Teaching International, 45(4): 375-387.

Davies M (2011). Concept mapping, mind mapping and argument mapping: What are the differences and do they matter?. Higher Education, 62(3): 279-301.

Jablokow KW, DeFranco JF, Richmond SS, Piovoso MJ, and Bilén SG (2015). Cognitive style and concept mapping performance. Journal of Engineering Education, 104(3): 303-325.

Katagall R, Dadde R, Goudar RH, and Rao S (2015). Concept mapping in education and semantic knowledge representation: An illustrative survey. Procedia Computer Science, 48: 638-643.

Krejcie RV and Morgan DW (1970). Determining sample size for research activities. Educational and Psychological Measurement, 30(3): 607-610.

Liu X, Zhang T, Tao L, Ren J, Li B, and Du M (2015). Online mindmap as interface of electronic resource integration and sharing. Journal of Shanghai Jiaotong University (Science), 20(1): 101-105.
Londers E, Van Hemelrijck I, Totté N, and Berbers Y (2015). Concept mapping: An innovative tool for curriculum development. In the $43^{\text {rd }}$ Annual SEFI Conference, Orléans, France.

MacKinnon G, Bailey R, Livingston P, Provencal VL, and Saklofske J (2014). Predispositions to concept mapping: Case studies of four disciplines in higher education. In: Infanthaler D and Hanewald R (Eds.), Digital knowledge maps in education: 371392. Springer Nature, New York, USA.

Novak JD (2015). Concept Maps: An Ausubelian Perspective. In: Gunstone R (Ed.), Encyclopedia of science education: 202-209. Springer Netherlands, Amsterdam, Netherlands.

Rofi'i A, Rukmini D, and Hartono R (2014). Improving students' motivation in writing descriptive texts by using the mind mapping technique. English Education Journal, 4(2): 114-121.

Sekaran U (2006). Research method for business: A skill building approach. John Wiley and Sons, New York, USA.

Sherbone T (2014). Mapping in curriculum: How concept map can improve the effectiveness of course development. In: Okada A, Buckingham Shum S, and ShErBorNE T (Eds.), Advanced Information and Knowledge Processing: Knowledge Cartography: 193-208. Springer Verlag, London, UK.

Twardy C (2004). Argument maps improve critical thinking. Teaching Philosophy, 27(2): 95-116.

Vitulli, P, Giles RM, and Shaw Jr EL (2014). The effects of knowledge maps on acquisition and retention of visual arts concepts in teacher education. Education Research International, 2014: Article ID 902810, 12 pages. https:// doi.org/10.1155/2014/902810 